\title{
DISPOSISI MATEMATIS DAN PEMBELAJARAN HUMANIS BAGI MAHASISWA PENDIDIKAN MATEMATIKA
}

\author{
Yulis Jamiah \\ Pendidikan Matematika Universitas Tanjungpura Pontianak \\ Email:yulis_jamiah@yahoo.co.id
}

DOI: 10.26418/jpmipa.v9i2.26768

\begin{abstract}
This research purposed to obtain the overview of mathematical disposition of student mathematics education, especially the students who took number theory subject. In obtaining these overview will be applied by humanis mathematics learning model. The specific purpose of this research are: 1) describe mathematics disposition of the students; 2) describe the process of application model to increase mathematic dispositions of the student; 3) describe the effectiveness of application model. The purposes are achieved through several stages, including: 1) analyze the theoretical; 2) explore the characteristics of a mathematical disposition; (3) identify and analyze problems; (4) reviewing the learning model; (5) applying model to increase mathematic dispositions that based on observation; 6) gives a questionnaire about mathematical disposition; and 7) analyzing the data. The method used in this research is descriptive method. Based on the purpose that disclosed, the results of research: 1) mathematical disposition of the students after the application model, shows $74 \%$ very positive attitude; $24 \%$ positive attitude; and $2 \%$ doubtful attitude; 2) the process of application model that facilitates appearance of a mathematical disposition of the students based on ability cognitive domain, affective domain, and domain skills, showing the criteria very well and good; and 3) the application of humanis learning model effective to increase mathematical disposition of the students in Number theory subject.

Keywords: Humanis Mathematics Learning Model, Mathematical Dispositions
\end{abstract}

Misi Program Studi Pendidik-an Matematika FKIP Untan yang tertuang dalam borang akriditasi tahun 2015 adalah menyelenggarakan proses pembelajaran yang berkualitas melalui pembinaan, pengembangan, dan peningkatan mutu pembelajaran, penelitian, dan pengabdian kepada masyarakat yang berkaitan dengan pendidikan matematika di sekolah dan masyarakat dengan mengite-grasikan pendidikan karakter. Untuk mewujudkan proses pembelajaran berkualitas ini memerlukan komitmen dari civitas akademik, di antaranya dosen sebagai pelaksana perkuliahan atau pengampu mata kuliah.

Pengintegrasian antara pendi-dikan matematika dengan pendidikan karakter dapat diwujudkan 
melalui proses pembelajaran. Pembelajaran matematika merupakan kegiatan yang menggunakan fungsi dan nilai matematika sebagai alat untuk mencerdaskan, membentuk sikap, serta mengembangkan keterampilan mahasiswa. Selain itu, disposisi matematis atau apresiasi mahasiswa terhadap matematika yang berupa kecenderungan untuk berfikir dan bertindak secara positif terhadap matematika. Tindakan mahasiswa tersebut terwujud ketika mereka senantiasa percaya diri dalam menghadapi persoalan matematis, memiliki rasa keingintahuan yang tinggi, tekun, dan senantiasa melakukan refleksi terhadap hal-hal yang telah dilakukannya. Sebaliknya mahasiswa kurang mengapresiasi terhadap matematika merupakan salah satu hambatan dalam belajar matematika untuk mencapai prestasi belajar yang tinggi.

Fakta atau kenyataan yang sering diperlihatkan oleh mahasiswa, baik melalui pembimbingan skripsi, proses pembelajaran maupun UTS/ UAS memberikan apresiasi atau sikap yang kurang baik. Contohnya: 1) mahasiswa menyusun skripsi mau-nya instan tanpa memperlihatkan usaha yang keras, menulis kajian teori mengambil kutipan yang ada diskripsi terdahulu tanpa mencari sumber refrensi yang asli; 2) mahasiswa memperlihatkan sikap yang kurang disiplin untuk mengikuti perkuliahan atau pengumpulan tugas dengan jadwal yang sudah disepakati; 3) saat UTS/UAS, mahasiswa masih memperlihatkan sikap kurang percaya diri. Jika kenyatan ini terus berlangsung tanpa ada pembenahan atau upaya untuk mengatasi hal tersebut, sudah barang tentu akan mempengaruhi pribadi mahasiswa sebagai pendidik yang profesional.

Hasil penelitian Yulis, dkk (2013) menunjukkan bahwa pengembangan model pembelajaran matematika humanis sederhana berbasis nilai-nilai karakter ini, fokusnya, yakni pembelajaran yang memperhatikan adanya keterlibatan otak dan emosi mahasiswa dalam setiap kegiatan belajar, dengan mengaktualisasikan nilai karakter. Selain itu, hasil penelitian Yulis, dkk (2014) menyim-pulkan bahwa model pembelajaran matematika humanis berbasis nilai kearifan lokal dan nilai karakter bagi sekolah menengah pertama, di antaranya adalah model yang mengacu pada aspek pembelajaran matematika secara manusiawi yang menempatkan siswa sebagai subyek untuk membangun pengetahuannya dengan memahami kondisi dalam diri sendiri maupun lingkungan sekitar-nya, serta dapat membentuk nilai-nilai kemanusiaan pada diri siswa. Penerapan model pembela-jaran ini dapat melatih proses berpikir dan bernalar siswa dalam menarik simpulan, mengem-bangkan aktivitas kreatif siswa yang melibatkan imajinasi, intuisi, dan penemuan dengan mengembangkan pemikiran divergen, rasa ingin tahu, membuat prediksi, serta mengem-bangkan kemampuan siswa dalam memecahkan masalah dan menyam-paikan gagasan. Selanjutnya, hasil penelitian Yulis, dkk (2015) menunjukkan bahwa penerapan model pembelajaran matematika humanis yang mengaktulisasikan nilai integritas bagi mahasiswa menghasilkan kemampuannya untuk beragumentasi, berkomunikasi secara logis matematis, 
serta kreatif dan produktif berpikir kritis. Dengan kata lain, model pembelajaran ini mendorong mahasiswa tidak saja mampu mencari sebuah jawaban yang benar, tetapi juga membangun, mengkontruksi, dan mempertahankan solusi yang argumentatif dan masuk akal, serta memnculkan sikap kebersamaan, membangun suasana keakraban.

Dari uraian tersebut, yang menjadi permasalahan dalam peneli-tian ini: "Bagaimanakah disposisi matematis mahasiswa Program Studi Pendidikan Matematika melalui penerapan model pembelajaran matematika humanis pada mata kuliah Teori Bilangan, khususnya matari Pola \& Sejarah Bilangan, dan Induksi Matematika?" Untuk menja-wab permasalahan tersebut, dirinci dalam beberapa pertanyaan pene-litian: 1) seperti apakah disposisi matematis mahasiswa setelah penerapan model pembelajaran?; 2) bagaimana proses penerapan model pembelajaran matematika humanis untuk meningkatkan disposisi matematis mahasiswa?; dan 3) bagaimana efektivitas penerapan model pembelajaran matematika humanis untuk meningkatan disposisi matematis mahasiswa?

Proses pembelajaran humanis untuk membentuk prilaku siswa yang baik sangat dipengaruhi oleh kondisi kewibawaan dan kewiyataan yang ada pada diri guru selaku pendidik. Karena kondisi tersebut merupakan pilar pembelajaran. Kewibawaan dapat tercipta, jika guru mampu membangun sentuhan yang tinggi terhadap siswa sehingga terciptanya rasa aman dan nyaman bersama pendidiknya. Untuk mengkondisikan rasa aman dan nyaman dalam belajar ini, sangat perlu memperhatikan unsur-unsur kewibawaan, yaitu: 1) pengakuan dan penerimaan; 2) kasih sayang dan kelembutan; 3) penguatan; 4) tindakan tegas yang mendidik; dan 5) pengarahan dan keteladanan. Sementara unsur-unsur yang ada pada kewiyataan, yaitu: 1) penguasaan materi pembelajaran; 2) penerapan metode pembelajaran; 3) penggunaan alat bantu pembelajaran; 4) pengembangan lingkungan pembe-lajaran; dan 5) penyelenggaraan penilaian pembelajaran (Phil, 2012: 110). Pendidik yang mencintai profesinya demi kemajuan peserta didik tidak akan merobohkan pilar pembelajaran. Selain itu, pendidik yang profesional tentu selalu mencerminkan prilaku yang dapat di teladani oleh pesreta didik, seperti berbahasa dengan bijak, dengan baik dan benar, dengan bahasa yang indah-indah, serta dengan sopan santun akan menumbuhkan pikiran dan sikap positif, menumbuhkan keakraban dan mempererat persaudaraan, menum-buhkan simpati dan empati, menjauhkan lawan bicara dari rasa tertekan atau terintimidasi (Chairil, 2012: 9). Prilaku-prilaku pendidik tersebut dapat mempengaruhi prilaku dan kemampuan yang dididik.

Pembelajaran matematika mempunyai tujuan, yakni membentuk kemampuan bernalar pada diri siswa yang tercermin melalui kemampuan berpikir kritis, logis, sistimatis dan memiliki sifat obyektif, jujur, disiplin dalam memecahkan suatu permasa-lahan baik dalam bidang matematika, bidang lain, maupun dalam kehidupan sehari-hari. Pembelajaran matematika dapat 
diartikan sebagai suatu upaya penataan lingkungan yang memberi nuansa agar program belajar matema-tika tumbuh dan berkembang secara optimal. Pengertian pembelajaran matematika secara sempit, yaitu proses pembelajaran dalam lingkup persekolahan, sehingga terjadi proses sosialisasi individu siswa dengan lingkungan-nya, seperti guru, sumber atau fasilitas, dan teman sesama siswa. Pembelajaran matematika humanis merupakan sebuah upaya yang memberikan dukungan bagi pengem-bangan kemampuan setiap individu secara holistik melalui perhatian terhadap mental, spiritual, etika, estetika, emosi, fisik dan pertumbuhan sosial, serta pengem-bangan scientific thinking, critical reasoning, problem solving skills, dan communication skill (Junaedi \& Asikin, 2012:116).

White (dalam Susilo, 2004) menjelaskan bahwa pembelajaran matematika humanistik mencakup dua aspek pembelajaran, yaitu: 1) pembelajaran matematika yang menempatkan siswa sebagai subjek untuk membangun pengetahuannya dengan memahami kondisi dalam bentuk nilai-nilai kemanusiaan, baik dalam diri sendiri siswa maupun lingkungan sekitarnya. Kreativitas guru untuk memfasilitasi kegiatan belajar siswa dengan berbagai metode dan kreativitas siswa sangat diperlukan untuk menemukan atau membangun pengetahuannya sebagai penunjang keberhasilan tujuan bela-jarnya; 2) pembelajaran matematika yang manusiawi berkaitan dengan usaha merekonstruksi matematika sekolah, sehingga matematika dapat dipelajari dan dialami sebagai bagian dari kehidupan manusia.

Menurut NCTM (2000:11), terdapat enam prinsip untuk menga-tasi belajar matematika sekolah, yakni: 1) ekuitas, keunggulan dalam pendidikan matematika membutuh-kan ekuitas, harapan yang tinggi dan dukungan yang kuat bagi semua siswa; 2) kurikulum, kurikulum dimaksudkan lebih dari sekumpulan kegiatan: hal itu harus koheren, terfokus pada matematika yang dianggap penting, dan diartikulasikan secara baik melalui penilaian; 3) pengajaran, pengajaran matematika yang efektif membutuhkan pemaham-an terhadap apa yang siswa ketahui dan siswa perlukan untuk belajar dan kemudian tantangan serta dorongan untuk belajar secara baik; 4) belajar, siswa harus belajar matematika dengan pemahaman, secara aktif membangun pengetahuan baru dari pengalaman dan pengetahuan sebe-lumnya, 5) assessment, penilaian harus mendukung pembelajaran matematika yang dianggap penting dan memberikan informasi yang berguna bagi guru dan siswa, 6) teknologi, teknologi sangat penting dalam proses belajar mengajar matematika, hal ini mempe-ngaruhi matematika yang diajarkan dan meningkatkan proses belajar siswa.

Selain itu, Reys, et al (Rachmawati, 2008:2) mengemuka-kan beberapa prinsip pembelajaran matema-tika secara spesifik, di antaranya: a) melibatkan keaktifan peserta didik; b) disesuaikan dengan karakteristik per-kembangan peserta didik; c) merupakan kegiatan yang berkesinambungan; d) mampu me-ngembangkan kemampuan 
berbahasa yang bersifat integral; e) pendidik harus mampu menyajikan pertanya-an-pertanyaan yang baik yang dapat memfasilitasi kegiatan belajar dan mampu menstimulasi proses berpikir peserta didik; f) peserta didik diberikan kesempatan memanipulasi alat peraga; g) pendidik merupakan model dalam proses pembelajaran matematika sehingga seluruh perilaku yang ditampilkan pendidik dapat mempengaruhi kemampuan belajar peserta didik; h) matematika yang diajarkan tanpa melalui tahapan pembelajaran matematika yang tepat akan menimbulkan kecemasan terha-dap matematika itu sendiri; i) adanya keseimbangan perlakuan peserta didik laki-laki dan perempuan dalam proses pembelajaran matematika; dan $\mathrm{j}$ ) kegiatan pembelajaran matematika harus mampu meningkatkan keteram-pilan dalam mengingat.

Keterampilan mengajarkan konsep matematika bukan hanya prinsip pembelajarannya saja yang diperhatikan, namun mengajarkan keterkaitan antara konsep-konsep matematika perlu dipertimbangkan. Soedjadi (2004); Bambang (2007), menyatakan bahwa beberapa karak-teristik pembelajaran matematika yang perlu dipertimbangkan, yaitu: 1) Pembelajaran matematika berjen-jang/bertahap: Materi pembelajaran diajarkan secara berjenjang atau bertahap, yaitu dari hal konkrit ke abstrak, hal yang sederhana ke kompleks, atau dari konsep mudah ke konsep yang lebih sukar; 2) Pembelajaran matematika mengikuti metoda spiral: Setiap mempelajari konsep baru perlu memperhatikan konsep atau bahan yang telah dipelajari sebelumnya. Bahan yang baru selalu dikaitkan dengan bahan yang telah dipelajari. Pengulangan konsep dalam bahan ajar dengan cara memperluas dan memperdalam adalah perlu dalam pembelajaran matematika (spiral melebar dan menaik); 3) Pembelajaran matema-tika menekankan pola pikir deduktif: Matematik adalah deduktif, mate-matika tersusun secara deduktif aksiomatik. Namun demikian, ha-rus dapat dipilihkan pendekatan yang cocok dengan kondisi peserta didik; dan 4) Pembelajaran mate-matika menganut kebenaran konsistensi: Kebenaran-kebenaran dalam matematika pada dasarnya merupakan kebenaran konsistensi, tidak bertentangan antara kebenaran suatu konsep dengan yang lainnya. Suatu pernyataan dianggap benar bila didasarkan atas pernyataan yang terdahulu yang telah diterima kebenarannya.

Kilpatrick, et al (2001) menamakan disposisi matematis sebagai productive disposition, yakni pandangan terhadap matematika sebagai sesuatu yang logis, dan meng-hasilkan sesuatu yang berguna. Lebih lanjut dikatakannya, disposisi matematika adalah kecenderungan (i) memandang matematika sesuatu yang dapat dipahami, (ii) merasakan matematika sebagai sesuatu yang berguna dan bermanfaat, (iii) meyakini usaha yang tekun dan ulet dalam mempelajari matematika akan membuahkan hasil, dan (iv) melakukan perbuatan sebagai pebelajar dan pekerja matematika yang efektif.

Menurut NCTM (2000: 4), disposisi matematika memuat tujuh 
komponen. Adapun komponenkomponen itu sebagai berikut, (i) percaya diri dalam menggunakan matematika, (ii) fleksibel dalam melakukan kerja matematika (bermatematika), (iii) gigih dan ulet dalam mengerjakan tugas-tugas matematika, (iv) penuh memiliki rasa ingin tahu dalam bermatematika, (v) melakukan refleksi atas cara berpikir, (vi) menghargai aplikasi matematika, dan (vii) mengapresiasi peranan matematika.

Disposisi matematik menurut Sumarmo (2010) adalah keinginan, kesadaran, kecenderungan dan dedikasi yang kuat pada diri siswa atau mahasiswa untuk berpikir dan berbuat secara matematik. Polking (dalam Sumarmo, 2010) mengemu-kakan bahwa disposisi matematik menunjukkan 1) rasa percaya diri dalam menggunakan matematika, memecahkan masalah, memberi alasan dan mengkomunikasikan gagasan; 2) fleksibilitas dalam menyelidiki gagasan matematik dan berusaha mencari metoda alternatif dalam memecahkan masalah; 3) tekun mengerjakan tugas matematik; 4) minat, rasa ingin tahu (curiosity), dan dayatemu dalam melakukan tugas matematik; 5) cenderung memonitor, merepleksikan performance dan penalaran mereka sendiri; 6) menilai aplikasi matematika ke situasi lain dalam matematika dan pengalaman sehari-hari; 7) apresiasi (appre-ciation) peran matematika dalam kultur dan nilai, matematika sebagai alat, dan sebagai bahasa.

Pembentukan

dasar

kepribadi-an mahasiswa tidak dapat dilepaskan dari soal-soal penanaman nilai-nilai (transfer of value).
Pembelajaran matematika merupakan kegiatan yang menggunakan fungsi dan nilai mate-matika sebagai alat untuk mencapai tujuan yang ditetapkan. Dalam melakukan proses pembelajaran matematika, pendidik berupaya meningkatkan atau selalu menum-buhkan sikap mahasiswa yang selalu mengapresiasi nilai yang tersirat dalam matemateka. Pada hakekatnya, matematika itu sarat dengan nilai-nilai, seperti: nilai kejujuran, cermat, ketelitian, konsistensi, ulet, tekun, percaya diri, kerja keras dan tanggungjawab. Melalui pemahaman nilai-nilai tersebut diharapkan maha-siswa dapat tumbuh kesadaran dan kemauan untuk mempraktekkan segala sesuatu yang dipelajarinya. Dengan pembelajaran matematika, diharapkan mahasiswa dapat mem-pelajari proses berpikir ilmiah terhadap kerangka konseptual dan struktur matematika dengan kehidupan sehari-hari.

\section{METODE}

Penelitian ini berupa suatu penerapan model pembelajaran matematika untuk meningkatkan disposisi matematis bagi mahasiswa Program Studi Pendidikan Mate-matika. Metode penelitian yang digunakan dalam penelitian ini adalah metode deskriptif. Metode deskriptif merupakan suatu prosedur peme-cahan masalah yang diselidiki dengan menggambarkan atau melukiskan keadaan subyek atau obyek penelitian saat penelitian berlangsung berda-sarkan fakta-fakta yang tampak atau sebagaimana adanya (Nawawi, 2005).

Penelitian dilaksanakan di FKIP Untan Pontianak, dengan subyeknya mahasiswa Program Studi Pendidikan 
Matematika. Penjaringan dan pengumpulan data dilakukan dengan berbagai cara, baik tes dan non tes melalui: tes verbal maha-siswa, dokumentasi, observasi, dan angket. Teknik analisis data yang digunakan adalah teknik secara kualitatif dan kuantitatif untuk saling melengkapi.

Penelitian ini dilaksanakan dengan mengadopsi model yang telah dikembangkan oleh Tim Peneliti (Yulis, dkk; 2013; 2014; 2015). Prosedur pelaksanaannya diuraikan berikut ini.

1. Menganalisis teori tentang mo-del pembelajaran dan disposisi matematis.

2. Mengeksplor karakteristik atau indikator disposisi matematis yang termuat dalam kurikulum pada Program Studi Pendidikan Matematika, khususnya pada mata kuliah Teori Bilangan;

3. Mengidentifikasi dan mengkaji permasalahan yang ditemukan pada langkah ke-2 dan menin-jaunya dari aspek keseimbang-an antara sikap, keterempilan dan pengetahuan mahasiswa; serta pemanfaatan pembela-jaran matematika humanis;

4. Mengkaji model pembelajaran matematika humanis yang diadopsi dari model yang telah dikembangkan oleh TIM pengembang sebelumnya, dan menyusun instumen berupa lembar observer, kisi-kisi angket dan angket disposisi matematis.

5. Menerapkan model pembele-jaran humanis untuk mening-katkan disposisi matematis yang disertai pengamatan penerapan model tersebut;
6. Memberikan angket setelah penerapan model

7. Menganlisis data dan membuat laporan akhir

\section{HASIL DAN PEMBAHASAN}

1. Disposisi Matematis

Dari hasil angket terhadap mahasiswa kelas A-1 dan B-1 semester tiga tahun akademik 2016/2017 Program Sudi Pendidikan Matematika, diperoleh informasi yang berkaitan dengan tanggapan mahasiswa terhadap pembelajaran matematika humanis pada mata kuliah Teori Bilangan dengan bahan kajian Pola dan Sejarah Bilangan, serta Induksi matematika. Tanggapan mahasiswa terfokus pada peng-gungkapan kecendrungan mahasiswa untuk berpikir dan bersikap positif terhadap matematika, serta bertindak positif ketika belajar matematika.

Angket untuk mengungkap tanggapan mahasiswa, terdiri dari 33 pernyataan. Karakteristik pernyataan yang diungkap mengacu pada indikator disposisi matematis, yaitu: 1) percaya diri dalam belajar mate-matika; 2) fleksibel dalam melakukan kerja matematia; 3) gigih dan ulet dalam mengerjakan tugas-tugas matematika; 4) memiliki rasa ingin tahu dalam bermatematika; 5) melakukan refleksi atas cara berpikir; 6) menghargai aplikasi matematika; dan 7) mengapresiasi peran mate-matika. Pernyataan-pernyataan yang diajukan dalam angket dijawab sesuai tanggapan mahasiswa dengan membubuhkan tanda tanda 
ceklis pada kolom yang telah disediakan.

Hasil transformasi skor respon mahasiswa terhadap pelaksanaan pembelajaran matematika diproses dari skala ordinal ke skala interval. Untuk melihat jawaban mahasiswa tentang responnya, maka perlu ditentukan rentangan yang menjawab selalu, sering, jarang, dan tidak pernah. Sikap masing-masing responden dapat dibuat distribusi frekwensi dan persentasi tanggapan/ sikap mahasiswa terhadap pembe-lajaran matematika sebagai berikut:

Tabel 1. Tanggapan mahasiswa terhadap pembelajaran matematika.

SIKAP FREKWENSI PERSENTASE

\begin{tabular}{ccc}
\hline $\mathrm{SN}$ & 0 & $0 \%$ \\
\hline $\mathrm{N}$ & 0 & $0 \%$ \\
\hline $\mathrm{R}$ & 1 & $2 \%$ \\
\hline $\mathrm{P}$ & 13 & $24 \%$ \\
\hline $\mathrm{SP}$ & 41 & $74 \%$ \\
\hline JUMLAH & 55 & $100 \%$ \\
\hline
\end{tabular}

Dari hasil persentase pada tabel di atas menunjukkan 41 orang mahasiswa (74\%) menyatakan tanggapan/sikap sangat positif, 13 orang mahasiswa (24\%) menyatakan tanggapan/sikap positif, dan 1 maha-siswa (2\%) menyatakan tanggapan ragu-ragu. Hal ini, dapat dinyatakan bahwa respon mahasiswa secara umum menunjukkan sikap positif dan sangat positif. Artinya, pembelajaran matematika humanis/menyenangkan yang merupakan pilar pembelajaran mahasiswa mengkontruksi pengala-mannya sendiri untuk menyelesaikan masalah tertentu. Dapat juga di artikan bahwa dalam pembelajaran matematika humanis, mahasiswa diberi kebebasan seluas-luasnya untuk mengungkapkan pendapatnya terhadap suatu permasalahan matematika yang diberikan oleh dosen dalam pembelajaran tersebut. Hal inilah yang menyebabkan mahasiswa mempunyai kecenderung-an untuk berpikir dan bertindak positif dalam belajar matematika.

Terbentuknya disposesi matematika yang tinggi atau kecen-drungan untuk berpikir dan bersikap positif terhadap matematika, serta bertindak positif ketika belajar matematika, maka mahasiswa akan lebih percaya diri dalam meng-gunakan matematika, fleksibel, gigih, dan ulet dalam menyelesaikan masalah matematika, memiliki keingintahuan untuk menemukan sesuatu yang baru, kecenderungan untuk merefleksi proses berpikir, dan menghargai peranan matematika, serta mengapresiasi peranan matema-tika. Karena disposisi matematis menurut Kilpatrick et al. (2001: 131) merupakan faktor utama dalam 
menentukan kesuksesan belajar matematika mahasiswa.

2. Penerapan Model Pembelajaran Matematika Humanis

Penerapan model pembela-jaran matematika humanis untuk meningkatkan disposisi matematika pada mata kuliah Teori Bilangan, khususnya bahan kajian Pola dan Sejarah Bilangan, dan Induksi Matematika. Penerapan model tersebut dalam setting pembelajaran kelompok, pelaksanaannya selama empat kali pertemuan (4 x 150 menit) pada tahun akademik 2016/2017. Metode pembelajaran yang diguna-kan sifatnya bervariasi, dan media yang digunakan selama menerapkan model pembelajaran adalah LCD.

Rekapitulasi hasil observasi dari proses penerapan model pembe-lajaran matematika humanis untuk meningkatkan disposisi matematika pada mata kuliah Teori Bilangan, khususnya bahan kajian Pola dan Sejarah Bilangan, dan Induksi Matematika disajikan pada tabel sebagai berikut. Tabel 2 dan Tabel 3 merupakan hasil pengamatan domain kognitif, Tabel 4 merupakan rata-rata hasil pengamatan domain afektif, dan Tabel 5 merupakan rata-rata hasil pengamatan domain keterampilan.

Tabel 2. Hasil pengamatan domain kognitif mahasiswa kelas A-1 materi pola dan sejarah bilangan.

\begin{tabular}{|c|c|c|c|c|c|c|c|c|c|}
\hline \multirow[b]{2}{*}{ No } & \multirow{2}{*}{$\begin{array}{l}\text { Aspek Yang Diamati } \\
\text { Domain Kognitif }\end{array}$} & \multicolumn{6}{|c|}{ Skor Kelompok } & \multirow[b]{2}{*}{$\begin{array}{l}\text { Total } \\
\text { Skor }\end{array}$} & \multirow{2}{*}{$\begin{array}{c}\text { Rata-rat: } \\
\text { Skor }\end{array}$} \\
\hline & & I & II & $\begin{array}{c}\text { II } \\
\text { I }\end{array}$ & IV & $\mathbf{V}$ & VI & & \\
\hline 1 & $\begin{array}{l}\text { Mengenalkan sejarah } \\
\text { bilangan dan } \\
\text { umeresinya }\end{array}$ & 4 & 4 & 4 & 3 & 3 & 4 & 22 & 3,7 \\
\hline 2 & $\begin{array}{l}\text { Membedakan angka } \\
\text { (digit) dengan } \\
\text { bilangan }\end{array}$ & 3 & 3 & 3 & 2 & 2 & 3 & 16 & 2,7 \\
\hline 3 & $\begin{array}{l}\text { Menentukan variasi } \\
\text { pola bilangan }\end{array}$ & 4 & 4 & 4 & 2 & 3 & 3 & 20 & 3,3 \\
\hline 4 & $\begin{array}{l}\text { Mengindentifikasi } \\
\text { ciri/karakteristik dari } \\
\text { bentuk pola bilangan }\end{array}$ & 3 & 3 & 3 & 2 & 2 & 2 & 15 & 2,5 \\
\hline \multicolumn{8}{|c|}{ Jumlah } & \multirow[b]{2}{*}{$\mathbf{x}$} & 12,2 \\
\hline \multicolumn{3}{|c|}{ Persentase Pemahaman : } & Skor & Iuml & iRat & $r a t$ & Skor & & $76,25 \%$ \\
\hline
\end{tabular}

Berdasarkan analisis data dan diperlihatkan pada tabel di atas diperoleh nilai persentase pemaham-an mahasiswa kelas A-1 dari materi yang berbeda dengan skor $76,25 \%$ dan $88,54 \%$.
Masing-masing per-sentase pemahaman mahasiswa tersebut menunjukkan pemahaman berdasarkan kiriteria kualitas yang dilakukan mahasiswa berkatagori baik dan sangat baik. Artinya, 
Disposisi Matematis dan Pembelajaran Humanis 21

secara umum konsep-konsep yang terdapat dalam materi Pola dan Sejarah Bilangan; Induksi
Matema-tika dipahami dengan baik.

Tabel 3. Hasil pengamatan domain kognitif mahasiswa kelas A-1 materi induksi matematika.

\begin{tabular}{|c|c|c|c|c|c|c|c|c|c|}
\hline \multirow{2}{*}{ No } & \multirow{2}{*}{$\begin{array}{c}\text { Aspek Yang } \\
\text { Diamati Domain } \\
\text { Kognitif }\end{array}$} & \multicolumn{6}{|c|}{ Skor Kelompok } & \multirow{2}{*}{$\begin{array}{l}\text { Total } \\
\text { Skor }\end{array}$} & \multirow{2}{*}{$\begin{array}{c}\text { Rata-rata } \\
\text { Skor }\end{array}$} \\
\hline & & $\mathbf{I}$ & II & III & IV & $\mathbf{v}$ & VI & & \\
\hline 1 & $\begin{array}{l}\text { Membuktikan } \\
\text { teorema dengan } \\
\text { cara induksi } \\
\text { matematika }\end{array}$ & 3 & 4 & 4 & 3 & 3 & 4 & 21 & 3,5 \\
\hline 2 & $\begin{array}{l}\text { Menuliskan } \\
\text { algoritma } \\
\text { pembuktian dengan } \\
\text { induksi matematika }\end{array}$ & 3 & 4 & 4 & 3 & 4 & 3 & 21 & 3,5 \\
\hline 3 & $\begin{array}{l}\text { Menentukan basis } \\
\text { untuk induksi } \\
\text { dalam suatu } \\
\text { pembuktian }\end{array}$ & 3 & 4 & 4 & 4 & 4 & 3 & 22 & 3,7 \\
\hline 4 & $\begin{array}{l}\text { Terampil } \\
\text { menggunakan } \\
\text { sifat-sifat notasi } \\
\text { sigma }\end{array}$ & 3 & 4 & 4 & 4 & 3 & 3 & 21 & 3,5 \\
\hline \multicolumn{8}{|c|}{ Jumlah } & \multirow[b]{2}{*}{ x 100} & 14,2 \\
\hline $\begin{array}{l}\text { Per } \\
\%\end{array}$ & entase Pemahaman & & $\frac{u m l}{a k s i}$ & Rat & $r a t$ & kor & & & $88,54 \%$ \\
\hline
\end{tabular}

Berdasarkan analisis data diperoleh nilai persentase prilaku/ sikapnya $93,75 \%$ untuk mahasiswa kelas A-1; Mengacu kriteria kualitas yang dilakukan mahasiswa, masing-masing persentase prilaku/sikap tersebut menunjukkan prilaku/sikap yang sangat baik. Artinya, secara umum mahasiswa memberikan apresiasi yang baik atau merasakan nyaman terhadap penerapan model pembelajaran dalam materi Pola dan Sejarah Bilangan, serta materi Induksi Matematika. Sikap inilah yang sangat diharapkan muncul dalam prilaku mahasiswa.
Berdasarkan analisis data diperoleh nilai persentase keteram-pilan $82,3 \%$ untuk mahasiswa kelas A-1. Mengacu kriteria kualitas yang dilakukan mahasiswa, masing-masing persentase keterampilan tersebut menunjukkan prilaku/sikap yang sangat baik dan baik. Artinya, secara umum keterampilan dalam: mempresentasikan hasil diskusi; me-ngajukan atau menjawab pertanyaan saat diskusi; dan menciptakan suasana belajar menyenangkan pada saat penerapan model pembelajaran dalam materi Pola dan Sejarah Bilangan, Induksi matematika 
menunjukkan keterampilan baik.

diharapkan muncul dalam Keterampilan inilah yang sangat pribadi-pribadi mahasiswa.

Tabel 4. Rata-rata Hasil Pengamatan Domain Afektif Mahasiswa Kelas A-1

\begin{tabular}{|c|c|c|c|c|c|c|c|c|c|}
\hline \multirow[b]{2}{*}{ No } & \multirow{2}{*}{$\begin{array}{c}\text { Aspek Yang Diamati Domain } \\
\text { Afektif }\end{array}$} & \multicolumn{6}{|c|}{ Skor Kelompok } & \multirow{2}{*}{$\begin{array}{l}\text { Total } \\
\text { Skor }\end{array}$} & \multirow{2}{*}{$\begin{array}{c}\text { Rata-rata } \\
\text { Skor }\end{array}$} \\
\hline & & $\mathbf{I}$ & $\begin{array}{l}\text { I } \\
\text { I }\end{array}$ & III & $\begin{array}{l}\mathbf{I} \\
\mathbf{V}\end{array}$ & $\mathbf{V}$ & $\begin{array}{l}\text { V } \\
\mathbf{I}\end{array}$ & & \\
\hline 1 & $\begin{array}{l}\text { Muncul nilai peduli/perhatian, } \\
\text { di antaranya mahasiswa peka } \\
\text { terhadap perasaan orang lain, } \\
\text { mencoba untuk membantu } \\
\text { teman yang membutuhkan }\end{array}$ & 4 & 4 & 4 & 4 & 4 & 3 & 23 & 3,8 \\
\hline 2 & $\begin{array}{l}\text { Muncul nilai percaya diri } \\
\text { dengan menunujkkan } \\
\text { kepercayaan terhadap } \\
\text { kemampuan dalam } \\
\text { mempresentasikan materi hasil } \\
\text { diskusi }\end{array}$ & 4 & 4 & 4 & 3 & 4 & 4 & 23 & 3,8 \\
\hline 3 & $\begin{array}{l}\text { Muncul nilai menghargai/ } \\
\text { persahabatan, di antaranya } \\
\text { mahasiswa memperlakukan } \\
\text { teman dengan baik, sopan dan } \\
\text { hormat, peka terhadap } \\
\text { perasaan orang lain, tidak } \\
\text { pernah menghina atau } \\
\text { mempermainkan teman/dosen, } \\
\text { tidak pernah mempermalukan } \\
\text { teman }\end{array}$ & 4 & 4 & 3 & 4 & 4 & 4 & 23 & 3,8 \\
\hline 4 & $\begin{array}{l}\text { Muncul nilai } \\
\text { ketelitian/kecrmatan dan nilai } \\
\text { sabar, di antaranya mahasiswa } \\
\text { mengerjakan tugas dengan } \\
\text { tekun dgn penuh keikhlasan } \\
\text { dan tanggungjawab } \\
\end{array}$ & 4 & 4 & 4 & 3 & 3 & 4 & 22 & 3,6 \\
\hline 5 & $\begin{array}{l}\text { Muncul nilai kebersamaan, di } \\
\text { antaranya mahasiswa saling } \\
\text { membantu dalam mengerjakan } \\
\text { tugas kelompok atau terlihat } \\
\text { saling membantu saat } \\
\text { berdiskusi }\end{array}$ & 4 & 4 & 4 & 4 & 4 & 4 & 24 & 4 \\
\hline \multirow[t]{2}{*}{6} & $\begin{array}{l}\text { Muncul nilai keingintahuan, di } \\
\text { antaranya mahasiswa cepat } \\
\text { tanggap dengan apa yang } \\
\text { dilihatnya, cepat bertanya } \\
\text { kalau tidak tahu tentang } \\
\text { sesuatu. }\end{array}$ & 4 & 3 & 4 & 3 & 3 & 3 & 20 & 3,3 \\
\hline & \multicolumn{5}{|c|}{ Jumlah } & & & & 22,5 \\
\hline \multicolumn{2}{|c|}{ Persentase Prilaku/sikap $=$} & \multicolumn{4}{|c|}{ Jumlah Rata-rata Skor } & $\mathbf{x}$ & $100 \%$ & & $93,75 \%$ \\
\hline
\end{tabular}


Disposisi Matematis dan Pembelajaran Humanis 23

Tabel 5. Rata-rata Hasil Pengamatan Domain Keterampilan Mahasiswa Kelas A-1

\begin{tabular}{|c|c|c|c|c|c|c|c|c|c|}
\hline \multirow{2}{*}{ No. } & \multirow{2}{*}{$\begin{array}{c}\text { Aspek Yang Diamati } \\
\text { Domain Keterampilan }\end{array}$} & \multicolumn{6}{|c|}{ Skor Kelompok } & \multirow{2}{*}{$\begin{array}{l}\text { Total } \\
\text { Skor }\end{array}$} & \multirow{2}{*}{$\begin{array}{l}\text { Rata-rata } \\
\text { Skor }\end{array}$} \\
\hline & & I & II & III & IV & $\mathbf{V}$ & $\mathbf{V}$ & & \\
\hline 1 & $\begin{array}{l}\text { Terampil } \\
\text { mempresentasikan dan } \\
\text { memaparkan hasil diskusi } \\
\text { kelompok }\end{array}$ & 4 & 4 & 3 & 3 & 3 & 4 & 21 & 3,5 \\
\hline 2 & $\begin{array}{l}\text { Terampil/terbiasa untuk } \\
\text { mengajukan } \\
\text { pertanyaan-pertanyaan } \\
\text { yang kritis }\end{array}$ & 3 & 4 & 3 & 2 & 3 & 3 & 18 & 3 \\
\hline 3 & $\begin{array}{l}\text { Terampil/terbiasa untuk } \\
\text { menanggapi } \\
\text { pertanyaan-pertanyaan } \\
\text { yang diajukan baik dari } \\
\text { teman sekelompok atau } \\
\text { berasal dari kelompok } \\
\text { lainnya }\end{array}$ & 4 & 4 & 3 & 2 & 2 & 3 & 18 & 3 \\
\hline 4 & $\begin{array}{l}\text { Terampil/terbiasa } \\
\text { menciptakan suasana } \\
\text { belajar yang } \\
\text { menyenangkan }\end{array}$ & 4 & 4 & 3 & 3 & 4 & 4 & 22 & 3,7 \\
\hline \multicolumn{9}{|c|}{ Jumlah } & 13,2 \\
\hline \multicolumn{7}{|c|}{ Persentase Keterampilan $=\frac{\text { Jumlah Rata }- \text { rata } \text { Skor }}{-}$} & \multicolumn{2}{|c|}{$100 \%$} & $82,3 \%$ \\
\hline
\end{tabular}

Hasil observasi dan berdasar-kan anlaisis data tentang proses penerapan model pembelajaran matematika humanis yang memfa-silitasi disposisi matematis mahasiswa pada mata kuliah Teori Bilangan, khususnya bahan kajian Pola dan Sejarah Bilangan, dan Induksi matematika, diperoleh nilai persentase tindakan yang dilakukan dosen 88,3\%. Mengacu kriteria kualitas tindakan dosen mengkata-gorikan bahwa proses perkuliahan yang dilaksanakan adalah baik.

\section{Efektivitas Penerapan Model}

Model pembelajaran matema-tika humanis untuk meningkatkan disposisi matematis ini sebagai modifikasi dari model pembelajaran kooperatif dengan mengacu kepada paradigma pembelajaran konstruktivis-me. Model pembelajaran ini ber-tujuan untuk mengembangkan daya matematis mahasiswa secara maksimal dan kemampuan berargumentasi dan berkomunikasi logis, serta mengem-bangkan kreativitas dan kemampuan berfikir tingkat tinggi, serta mengem-bangkan suasana pembelajaran yang menyenangkan (Yulis, dkk; 2013). Proses

pembelajaran matema-tika humanis untuk meningkatkan disposisi matematis yang diterapkan dalam penelitian ini, secara umum dapat terlaksana dengan baik. Terlaksananya pembelajaran tersebut, dikarenakan adanya berbagai faktor pendukung. 
Pembelajaran yang diterapkan, menggunakan struktur pengajaran seperti strategi yang dapat meningkatkan efektivitas pembela-jaran, yaitu dengan tahapan: persiapan, pelaksanaan, dan evaluasi. Untuk persiapan, menyiapkan rencana perkuliahan disusun sesuai format yang lazim dilengkapi media yang diperlukan. Pelaksanaannya melalui proses pembelajaran matema-tika humanis dengan memperhatikan pembentukan prilaku mahasiswa. Pembentukan prilaku mahasiswa yang baik tersebut sangatlah dipengaruhi oleh kondisi kewibawaan dan kewiyataan yang ada pada diri dosen selaku pendidik. Kewibawaan dapat tercipta, jika dosen mampu membangun sentuhan yang tinggi terhadap mahasiswa sehingga terciptanya rasa aman dan nyaman bersama pendidiknya, dengan memperhatikan unsur-unsur: 1) pengakuan dan penerimaan; 2) kasih sayang dan kelembutan; 3) penguatan; 4) tindakan tegas yang mendidik; dan 5) pengarahan dan keteladanan. Kewiyataan dapat muncul, jika dosen selaku pengampu mata kuliah menguasai: 1) materi pembelajaran; 2) metode pembela-jaran; 3) penggunaan alat bantu pembelajaran; pengembangan lingkungan pembela-jaran; dan 5) penyelenggaraan penilaian pembela-jaran (Phil., 2012: 110).

Membelajarkan mahasiswa agar mumpuni memerlukan peran-cangan suatu tahapan kegiatan perkuliahan yang lengkap dan sistematis, serta memuat kompetensi yang seimbang antara domain kognitif, domain afektif/sikap dan domain ketrampilan. Berdasarkan analisis hasil penilaian pengamatan pada domain kognitif, domain afektif, dan ketrampilan diperoleh rata-rata hasil 83,2\%. Jika hasil ini mengacu kriteria kualitas yang dilakukan mahasiswa, maka hasil penilaian tersebut menunjukkan katagori sangat baik. Pencapaian katagori yang sangat baik ini tidak terlepas dari pelaksanaan pembelajaran menye-nangkan yang sesuai dengan rencana. Selain itu, berdasarkan analisis terhadap angket yang mengungkap kecendrungan mahasiswa untuk ber-pikir dan bersikap positif terhadap matematika, serta bertidak positif ketika belajar matematika (disposisi matematis) terhadap proses pembe-lajaran matematika humanis, maka hasilnya menunjukkan respon yang baik dan sangat baik. Hal ini, sejalan dengan pendapat Wotruba dan Wright (dalam Yusufhadi, 2004) bahwa pelaksanaan pembelajaran sesuai dengan indikator yang direncanakan akan menghasilkan pembelajaran yang efektif, jika memperhatikan: pengorganisasian materi yang baik; 2) komunikasi yang efektif; 3) penguasaan dan antusiasme terhadap materi pelajaran; 4) sikap positif terhadap mahasiswa; 5) pemberian nilai yang adil; 6) kelu-wesan dalam pendekatan pembelajaran; dan 7) hasil belajar siswa yang baik.

Berdasarkan analisis hasil penilaian, yakni: 1) mahasiswa mem-berikan respon yang positif dan sangat positif terhadap 
pelaksanaan pembelajaran yang diterapkan, dan 2) hasil penilaian pengamatan terhadap penerapan pembelajaran yang mengacu domain kognitif, domain afektif, dan ketrampilan diperoleh rata-rata hasil penilaian sebesar $83,2 \%$. Hasil analisis tersebut dapat disimpulkan bahwa penerapan model pembelajaran matematika humanis efektif untuk meningkatan disposisi matematis mahasiswa pada mata kuliah Teori Bilangan, khususnya bahan kajian Pola \& Sejarah Bilangan, dan Induksi Matematika.

\section{SIMPULAN DAN SARAN}

\begin{tabular}{llr}
\multicolumn{2}{c}{ Keberhasilan proses } \\
pembela-jaran tergantung pada \\
berbagai aspek, di antaranya model \\
pembelajaran yang digunakan.
\end{tabular} Penggunaan model pembelajaran yang sesuai dan menarik dapat mendorong mahasiswa untuk mengoptimalisasi potensi yang dimilikinya dalam mempelajari materi ajar yang disajikan. Model pembelajaran ini mendorong maha-siswa tidak saja mampu mencari sebuah jawaban yang benar, tetapi juga membangun, mengkonstruksi, dan mempertahankan solusi yang argu-mentatif dan masuk akal, serta memnculkan sikap kebersamaan, membangun suasana keakraban.

Disposisi matematis mahasiswa setelah penerapan pembelajaran matematika humanis pada mata kuliah Teori Bilangan, khususnya matari Pola \& Sejarah Bilangan, dan Induksi Matematika, menunjukkan 41 mahasiswa (74\%) menyatakan sikap sangat positif, 13 mahasiswa (24\%) menyatakan tanggapan/sikap positif, dan 1 mahasiswa (2\%) menyatakan tanggapan/sikap ragu-ragu. Hasil ini menunjukkan bahwa mahasiswa pada umumnya lebih percaya diri dalam menggunakan matematika, fleksibel, gigih, dan ulet dalam menyelesaikan masalah matematika, memiliki keingintahuan untuk menemukan sesuatu yang baru, kecenderungan untuk merefleksi proses berpikir, dan menghargai peranan matematika, serta mengapresiasi peranan matematika.

Proses penerapan model pembelajaran matematika humanis yang memfasilitasi munculnya disposisi matematis melalui lembar pengamatan terungkap bahwa tindakan yang dilakukan dosen dalam menerapkan perkuliahan dengan rata-rata nilai persentase $88,3 \%$ yang berkategori sangat baik, kemampuan domain kognitif berkatagori sangat baik dan baik, kemampuan domain akektif berkatagori baik, dan kemampuan domain keterampilan berkatagori sangat baik dan baik.

Penilaian terhadap pelaksanaan pembelajaran yang diterapkan, mahasiswa memberikan respon yang positif dan sangat positif terhadap proses pembelajaran matematika humanis, begitu juga konstribusi kemampuan domain kognitif, kemampuan domain akektif dan kemampuan domain keterampilan berkatagori sangat baik dan baik. Hal ini, berarti penerapan model pembelajaran matematika humanis efektif untuk meningkatan disposisi matematis mahasiswa pada mata kuliah Teori Bilangan, khususnya matari Pola \& Sejarah Bilangan, dan Induksi Matematika.

Berdasarkan temuan dan hasil penelitian yang dituangkan dalam kesimpulan, terdapat beberapa saran yang dapat diajukan, karena secara 
umum hasil penelitian ini menun-jukan hasil yang baik, maka sangat diharapakan bagi dosen pengampu mata kuliah selain mata kuliah Teori Bilangan untuk menerapkan model pembelajaran matematika humanis sederhana yang dapat memfasilitasi disposisi matematis mahasiswa. Melalui pembelajaran ini diharapkan pengembangan kemampuan berfikir dan pembentukan sikap mahasiswa dapat dicapai secara optimal sesuai harapan kurikulum.

Untuk pejabat struktural yang membidangi bagian akademik diharapkan memberikan perhatian lebih besar terhadap kemampuan dosen, terutama berkaitan dengan usaha mengembangkan kemampuan kognitif, kemampuan afektif dan kemampuan keterampilan, serta disposisi matematis mahasisa, misalnya memberikan workshop atau lokakarya dengan mendatangkan para ahli bidang pengembangan pembela-jaran untuk bidang Pendidikan Matematika dan value Matematika.

\section{DAFTAR PUSTAKA}

Bambang, H. (2007). Representasi dalam Pembelajaran Matematika. Pontianak: STAIN Pontianak Press.

Chairif Effendi. (2012) Peranan Bahasa Melayu dalam Membangun Karakter Bangsa, Bahan Seminar Nasional di Hotel Aston Pontianak Tgl 5-6 Juni 2012

Junaidi dan M. Asikin. 2012. Pengembangan pembelajaran

Matematika
Humanistik untuk Meningkatkan Kemahiran Matematis, Unnes Journal of Mafhematicts Educatioan Research. http://journal.unnes.ac.id/sju/ index.php/ujmer. (on-line, diakses 10 Mei 2013).

Kilpatrick, J., Swafford, J., \& Findell, B. (2001). Adding it up: Helping children learn mathematics. Washington, DC. : National Academy Press.

National Council of Teachers of Mathematics. (2000). Principles and standards for school mathematics. Reston, VA: NCTM.

Nawawi, H. (2005). Metode Penelitian Bidang Sosial. Yogyakarta: UGM Univ Press

Phil Yanuar Kiram. (2012). Profesi Pendidik Seutuhnya dalam Perseptif Penyiapan Manusia Indonesia Generasi 2045. Materi Konvensi Nasional Pendidikan Indonesia (KONASPI) VII 2012 di Yogyakarta Tgl 31 Oktober 3 November 2012. Penerbit: UNY Press.

Rahmawati, Y. (2008). Pengembangan Matematika untuk Anak Usia Dini, Hasil Diklat Kerjasama antara Direktorat PTK PNF Ditjen PMPTK Dediknas dengan UPI Bandung.

Sumarmo, U. (2010). Berfikir dan Disposisi Matematik: Apa, 
Mengapa, dan Bagaimana

dikembangkan pada Peserta Didik.

https://www.scribd.com/doc/ 76353753/Berfikir-Dan-Disp osisi-Matematik-Utari

[on-line

diunduh 12-04-2016]

Soedjadi, R. (2004). Designing Instruction of Values in School Mathematics, Surabaya: FPMIPA UNESA

Susilo, Frans. 2004. Matematika Humanistik, Yogyakarta: Basis

Yulis J., dkk. (2015). Penguatan Nilai Integritas Melalui Pembelajaran Matematika Humanis Bagi Mahasiswa Pendidikan Matematika FKIP Untan Pontianak. Laporan Penelitian.

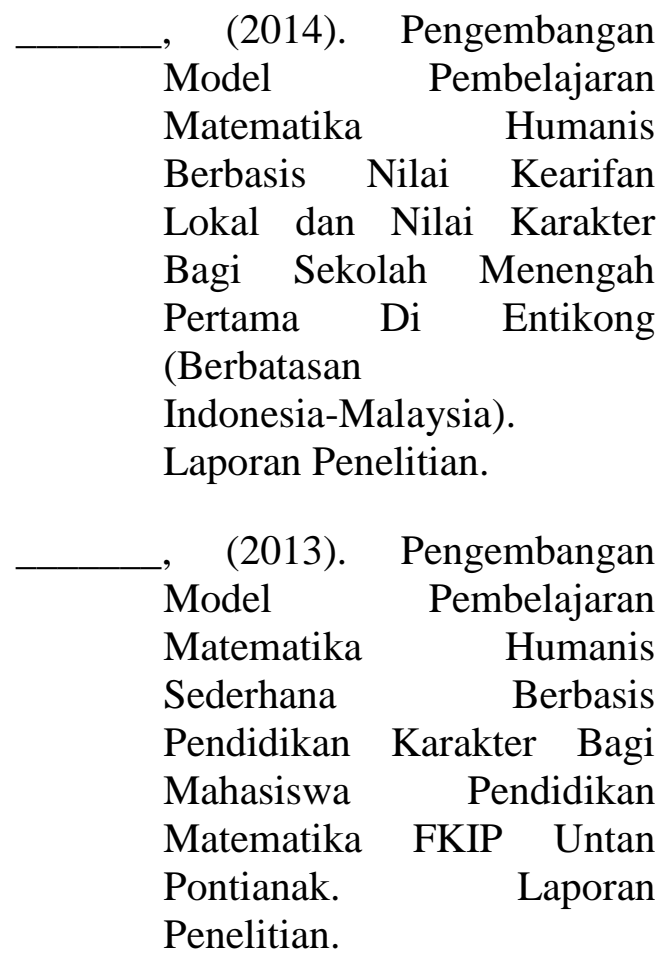

Yusufhadi Miarso. (2004). Menyemai Benih Teknologi Pendidikan. Jakarta: Prenada Media. 